\title{
HAY YIELD, QUALITY TRAITS AND INTERSPECIES COMPETITION OF FORAGE PEA - TRITICALE MIXTURES HARVESTED AT DIFFERENT STAGES
}

\author{
Özlem Önal AŞCI ${ }^{1}$, Zeki ACAR ${ }^{2}$, Yeliz Kaşko ARICI \\ ${ }^{1}$ Ordu University, Faculty of Agriculture, Department of Field Crops, Ordu, TURKEY \\ ${ }^{2}$ Ondokuz Mayis University, Faculty of Agriculture, Department of Field Crops, Samsun, TURKEY \\ ${ }^{3}$ Ordu University, Faculty of Agriculture, Department of Animal Science, Ordu, TURKEY \\ *Corresponding author: oasci@odu.edu.tr
}

Received: 08.06.2015

\begin{abstract}
The present study was conducted in two years under ecological conditions of Ordu Province to investigate the effects of different mixture ratios and harvest stages on hay yield, some quality traits and interspecies competition of forage pea-triticale mixtures. Leafed (Ü) and semi-leafless (U) forage pea (Pisum sativum $\mathbf{L}$.) cultivars and triticale (xTriticosecale Wittmack) were sown as monocrops and in different forage pea:triticale mixture ratios $(\mathbf{7 5 : 2 5}, \mathbf{5 0 : 5 0 , 2 5 : 7 5 )}$ and harvested at booting and milk-dough stage of triticale. Considering the total digestible dry matter and crude protein yields of the treatments together, it was observed that $T_{75}: \ddot{U}_{25}, T_{50}: \ddot{U}_{50}, T_{75}: U_{25}$ mixtures harvested at milk-dough stage of triticale produced high yields. In addition, leafed forage pea was found to be more aggressive than semi-leafless cv. in all mixtures.
\end{abstract}

Keywords: Competition, forage pea, mixture, triticale

\section{INTRODUCTION}

Forage pea is an annual cool-season forage crop commonly produced either for forages or seeds. Annual forage crops can be grown in winter period such as forage pea and vetches very important for feed production due to no need irrigation in Turkey. Only 5 million hectare agricultural areas can be irrigated and those areas are occupied vegetables and some industrial crops. Lodging following the flowering period is a critical issue in forage pea culture. Because lodging decrease yield and quality of forage crops and also causes difficulties in mechanization. Therefore, leafed and semi-leafless cultivars have been developed to prevent the yield losses due to lodging (Acikgoz, 2001). Previous researches revealed that monocrop cultivated semi-leafless cultivars grow steeper or more erected fashion than the leafed cultivars (Uzun and Acikgoz, 1998; Bilgili et al., 2010; Turk et al., 2011), however, different results were reported for yields of leafed and semi-leafless cultivars. For instance, Tamkoc et al. (2009) reported higher yields for semi-leafless cultivars than the leafed cultivars, but Uzun et al. (2005) indicated insignificant effects of leaf pattern on forage yields.

In intercropping systems, sowing, cultivar and even species used in mixtures, mixture ratio and stage of harvest may significantly affect the hay yields and quality of the mixture and such factors also affect the interspecies competition in mixtures. When the forage pea is sown in mixtures with oat or barley, it is recommended that the mixture should be harvested in milk-dough stage of the cereals in mixture (Asik, 2006; Uzun and Asik, 2012). Berkenkamp and Meeres (1987) indicated wheat and triticale as the least competitive cultivars when the forage pea is sown in mixtures with cereals like wheat, barley, triticale or oat. However, much information was not achieved in literature about the effects of leaf forms on interspecies competition in forage pea - triticale mixtures.

The present study was conducted to investigate the effects of mixture ratios and harvest stages on hay yields, some quality traits and interspecies competition of triticale - forage pea (leafed and semi-leafless) mixtures.

\section{MATERIALS AND METHODS}

The present study was conducted along the coastal sections of Ordu province of Turkey $\left(40^{\circ} 58^{\prime} \mathrm{N}, 37^{\circ} 56^{\prime} \mathrm{E}\right.$, $5 \mathrm{~m}$ altitude) during the growing seasons of 2010-11 and 2011-12 (between November and June). Experiments were conducted over clay-loam soils with $\mathrm{pH}$ of 6.3 and 7.5 , organic matter content of 44 and $50 \mathrm{~g} \mathrm{~kg}^{-1}$, available $\mathrm{P}$ contents of 4.1 and $13.3 \mathrm{ppm}$ and $\mathrm{K}$ contents of 690 and $700 \mathrm{ppm}$ in the first and second year of experiments, respectively ( 0 to $30 \mathrm{~cm}$ soil profile). 
Considering the experimental years and long-term precipitation and temperature values (Figure 1), the values were relatively different by the years.

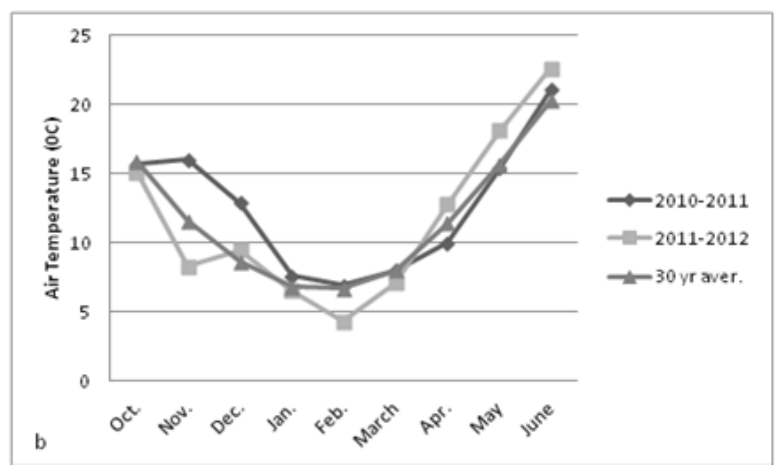

Figure1. Monthly precipitation (a) and mean air temperature (b) in Ordu province

Seed bed preparation was performed in October. Before seeding, $30 \mathrm{~kg}^{-1} \mathrm{~N}$ and $60 \mathrm{~kg}$ ha ${ }^{-1} \mathrm{P}_{2} \mathrm{O}_{5}$ were applied as ammonium nitrate and triple superphosphate in both years. Forage pea (leafed cv. Ürünlü (Ü) and semileafless cv. Ulubatli (U)) and Triticale (cv. Tatlicak (T)) were sown as monocrops and in mixtures (75 P:25 T, 50 $\mathrm{P}: 50 \mathrm{~T}$ and $25 \mathrm{P}: 75 \mathrm{~T}$ ) in the first and the last week of November of the first and second growing seasons. The seeding rates for forage pea and triticale monocrops were 100 and 500 seeds per $\mathrm{m}^{2}$, respectively (Mut et al., 2006; Acikgoz et al., 2009). While the number of triticale seeds in mixtures (75 P:25 T, $50 \mathrm{P}: 50 \mathrm{~T}$ and $25 \mathrm{P}: 75 \mathrm{~T}$ ) was 125,250 and 375 seeds per $\mathrm{m}^{2}$, it was 75,50 and 25 seeds per $\mathrm{m}^{2}$ for forage pea. The row spacing was $20 \mathrm{~cm}$ and seeds of both species were sown simultaneously within a row by hand. The plots were harvested at booting and milk-dough stage of triticale. While triticale was at booting stage, forage pea was at a stage which seeds were trace in the lowest pods in both years. Just as triticale was at milk-dough stage, forage pea was near maturity in the first year and was at a stage in which seeds were full size in lower pods and flowers opened in upper nodes in the second year. The experimental design was a randomized complete block with 18 plots (three monocultures and six mixtures of forage pea cultivars with triticale combined with harvest stage) and three replications. Plot size was 7 $\times 1.6 \mathrm{~m}$. The plots were kept free of weeds by hand hoeing when necessary. Plants were grown without supplemental irrigation in both growing seasons.

At each harvest, samples from a $4 \mathrm{~m}^{2}$ area of each plot were mowed from about $5 \mathrm{~cm}$ above the soil surface and separated as pea and triticale. The samples for each species from each plot were dried at $60{ }^{\circ} \mathrm{C}$ to a constant weight to determine hay yield (HY).

Crude protein contents (CPC), ADF and NDF of samples were determined using near infrared reflectance spectroscopy (NIRS) (Foss Nir Systems Model 6500 Win ISI II v 1.5). NIRS was calibrated using software program coded IC-0904FE. Their weighted averages were also calculated for mixtures. Digestible dry matter contents (DDMC) $(\%)$ were calculated from ADF ratios of hay samples by using the following equation (Horrocks and Vallentine, 1999).

Digestible dry matter content $(\mathrm{DDMC})(\%)=88.9-$ $(0.779 \times \mathrm{ADF} \%)$

Crude protein content was multiplied by hay yield to calculate crude protein yield and digestible dry matter content was multiplied by hay yield to calculate digestible dry matter yield (DDMY).

The advantage of intercropping and the effects of competition between two species used in a mixture were calculated by using different competition indices as follows: the land equivalent ratio (LER) was used as the criterion for mixed stand advantage as both pea and cereal were desired species in the mixtures. In particular, LER indicates the efficiency of intercropping for using the environmental resources compared with monocropping. The value of unity is considered as the critical value for this index. When LER is greater than one, the intercropping favors the growth and yield of the intercropped species, whereas when LER is lower than one, the intercropping negatively affects the growth and yield of the species (Mead and Willey, 1980). The LER was calculated as:

$$
\begin{gathered}
L E R=L E R_{\mathrm{p}}+L E R_{\mathrm{t}} \\
L E R_{\mathrm{p}}=\left(\frac{Y_{\mathrm{pi}}}{Y_{\mathrm{p}}}\right) \\
L E R_{\mathrm{t}}=\left(\frac{Y_{\mathrm{ti}}}{Y_{\mathrm{t}}}\right)
\end{gathered}
$$

Where $\mathrm{Y}_{p}$ and $\mathrm{Y}_{t}$ are the yields of pea and triticale, respectively as monocrops and $\mathrm{Y}_{p i}$ and $\mathrm{Y}_{t i}$ are the yields of pea and triticale, respectively as intercrops (Dhima et al., 2007).

Aggressivity is often used to indicate how much the relative yield increase in ' $a$ ' crop is greater than that of ' $b$ ' crop in intercropping (Agegnehu et al., 2006).The aggressivity is derived from the equation: 


$$
\begin{aligned}
& A_{t}=\left(\frac{Y_{t i}}{Y_{t} Z_{t i}}\right)-\left(\frac{Y_{p i}}{Y_{p} Z_{p i}}\right) \\
& A_{p}=\left(\frac{Y_{p i}}{Y_{p i} Z_{p i}}\right)-\left(\frac{Y_{t i}}{Y_{t} Z_{t i}}\right)
\end{aligned}
$$

Where $Z_{t i}$ is the sown proportion of triticale in mixture and $Z_{p i}$ is the sown proportion of pea in mixture (Dhima et al., 2007; Lithourgidis et al., 2011). If $\mathrm{A}_{t}=0$, both crops are equally competitive, if $\mathrm{A}_{t}$ is positive then the triticale is dominant, if $\mathrm{A}_{t}$ is negative then the triticale is the recessive species.

The competitive ratio (CR) is a method for assessing inter-specific competition between components of mixtures, gives an estimate of the competitive ability of the component crops (Dhima et al., 2007). The CR was calculated according to the following formula:

$$
\begin{aligned}
& C R_{t}=\left(\frac{L E R_{t}}{L E R_{p}}\right)\left(\frac{Z_{p i}}{Z_{t i}}\right) \\
& C R_{p}=\left(\frac{L E R_{p}}{L E R_{t}}\right)\left(\frac{Z_{t i}}{Z_{p i}}\right)
\end{aligned}
$$

The assumptions of data

normality and homogeneity of variance, which are prerequisite for ANOVA, were tested with the Anderson-Darling and the Levene tests, respectively. Variables were analysed by the three-way ANOVA (repeated randomized block design ANOVA where three factors are fixed), after means compared with Tukey's post-hoc test. The assumptions were not met for LER, so the LER were performed with the Friedman Test, Wilcoxon Signed Rank Test and Dunn post-hoc test. The Tukey and Dunn tests results were displayed in the form of letters (Duzgunes et al., 1987). All calculations were performed with Minitab 17 statistical software. The alpha level was set at $5 \%$.

\section{RESULTS AND DISCUSSION}

Since different sowing conditions of the years (Figure 1) altered sowing times, emergence of seedlings, growth of species and mixtures, response of species against different conditions, variance analysis revealed that year $\mathrm{x}$ harvest stage $\mathrm{x}$ treatment interactions were highly significant with regard to total hay yield $(\mathrm{p}<0.01$, Table 1). Sowing was performed almost 1 month earlier in the first year because of better weather conditions during the November of the first year. Also, autumn and winter seasons of the first year were warmer than the second year and there were more precipitation in the first year during the active growth periods of the plants (March, April and May) (Figure 1). Such favorable climate conditions provided especially the well-growth of triticale (while the average plant height was $150 \mathrm{~cm}$ in the first year, the value was observed as $80 \mathrm{~cm}$ in the second year. Data were not provided here), thus significant increases were observed in triticale yields. Forage pea also exhibited rapid growth in the first year right after sowing because of warmer weather but slightly influenced by winter colds. Besides, prolonged harvest times also resulted in increasing yield levels. Therefore, hay yields varied with years and harvest stages. When triticale was harvested at booting stage, significant differences were not observed in hay yields of the treatments both in the first and the second year $(p>0.05)$. Similar case is also valid for the average of years. In other words, average of years were not also significantly different when triticale was harvested at booting stage $(p>0.05)$ (Table 1). When triticale was harvested at milk-dough stage, hay yields of entire treatments of the second year were not significantly different from the yields obtained when triticale harvested at booting stage. In the first year, except for $\mathrm{U}_{100}$ treatment, total hay yields of entire treatments significantly increased with prolonged harvest times $(\mathrm{P}<0.05)$. When triticale was harvested at milk-dough stage, the highest hay yield of the first year was obtained from $\mathrm{T}_{75}: \mathrm{U}_{25}$ treatment and there were not significant differences between this treatment and the treatments $\mathrm{T}_{100}$, $\mathrm{T}_{75}: \ddot{U}_{25}$ and $\mathrm{T}_{50}: \mathrm{U}_{50}(\mathrm{p}>0.05)$. In the second year, the lowest hay yields were obtained from $\mathrm{U}_{100}$ and $\mathrm{T}_{25}: \mathrm{U}_{75}$ treatments and the differences between the other treatments were found to be non-significant $(p>0.05)$. Besides, except for $U_{100}$ and $\ddot{U}_{100}$ treatments, hay yields of all treatments significantly decreased in the second year when triticale was harvested at milk-dough stage (Table 1). All these findings indicated that $\mathrm{T}_{100}, \mathrm{~T}_{75}: \ddot{U}_{25}, \mathrm{~T}_{75}: \mathrm{U}_{25}$ and $\mathrm{T}_{50}: \mathrm{U}_{50}$ treatments sustained high yield levels in both years when triticale was harvested at milk-dough stage. As expected, increasing hay yields were observed with prolonged harvest times (Table 1). Previous studies also indicated milk-dough stage as the proper harvest period for forage pea intercropped with cereals (Asik, 2012; Uzun and Asik, 2012). Hay yields of mixtures were higher than the yields obtained from monocrop semi-leafless forage pea (cv. Ulubatl1) in both harvest periods. However, hay yield of mixtures harvested at milk-dough stage was lower than the hay yield of monocrop leafed forage pea (cv. Ürünlü) in the second year. Although previous researchers indicated that cereal - legume mixtures had higher yields than monocrop legumes (Dordas et al., 2012; Uzun and Asik, 2012), the present findings do not support those previous results. Since the species used in mixtures and mixture ratios effect the interspecies competition, performance of mixtures may vary from one ecology to another. Thusly, hay yields of the present mixtures were either higher or lower than monocrop triticale (Table 1). The present findings comply with the results of Dordas et al. (2012) indicating that yields of mixtures may either be higher or lower than monocrop cereal based on the cereal species and sowing rates. 
Table 1. Hay yield and pea ratio of hay of monocrops and mixtures of pea with triticale in different seeding ratio harvested at different stages

\begin{tabular}{|c|c|c|c|c|c|c|c|c|}
\hline \multirow{3}{*}{ Treatment } & \multicolumn{4}{|c|}{ Hay yield $\left(\mathrm{kg} \mathrm{ha}^{-1}\right)^{* *}$} & \multicolumn{4}{|c|}{ Forage pea ratio of hay $(\%)$} \\
\hline & \multicolumn{2}{|c|}{ 2010-11 } & \multicolumn{2}{|c|}{ 2011-12 } & \multicolumn{2}{|c|}{ 2010-11 } & \multicolumn{2}{|l|}{ 2011-12 } \\
\hline & Booting & Milk-dough & Booting & $\begin{array}{l}\text { Milk- } \\
\text { dough }\end{array}$ & Booting & $\begin{array}{l}\text { Milk- } \\
\text { dough }\end{array}$ & Booting & $\begin{array}{l}\text { Milk- } \\
\text { dough }\end{array}$ \\
\hline $\mathrm{T}_{100}$ & 5837 A b 1 & $23000 \mathrm{AB}$ a 1 & 3093 A a 1 & 4197 A a 2 & 0.00 & 0.00 & 0.00 & 0.00 \\
\hline$\ddot{U}_{100}$ & $4020 \mathrm{~A} \mathrm{~b} 1$ & 7993 E a1 & 3063 A a1 & 8970 A a 1 & 100.00 & 100.00 & 100.00 & 100.00 \\
\hline $\mathrm{U}_{100}$ & 1403 A a 1 & 2080 F a 1 & $1850 \mathrm{~A}$ a1 & 2237 B a 1 & 100.00 & 100.00 & 100.00 & 100.00 \\
\hline $\mathrm{T}_{75}: \ddot{\mathrm{U}}_{25}$ & 4460 A b 1 & $21450 \mathrm{AB}$ a 1 & 3777 A a 1 & $4513 \mathrm{~A}$ a 2 & 15.89 & 20.11 & 20.70 & 30.67 \\
\hline $\mathrm{T}_{50}: \ddot{\mathrm{U}}_{50}$ & 5230 A b1 & $17930 \mathrm{BCD}$ a 1 & 4143 A a 1 & $5113 \mathrm{~A}$ a 2 & 35.18 & 24.40 & 29.37 & 40.92 \\
\hline $\mathrm{T}_{25}: \ddot{U}_{75}$ & 5443 A b 1 & $14860 \mathrm{D}$ a1 & 3690 A a 1 & 5033 A a 2 & 51.58 & 36.16 & 51.47 & 63.52 \\
\hline $\mathrm{T}_{75}: \mathrm{U}_{25}$ & 5360 A b 1 & $23270 \mathrm{~A}$ a 1 & 3383 A a 1 & $7103 \mathrm{~A}$ a2 & 2.50 & 2.90 & 5.09 & 2.10 \\
\hline $\mathrm{T}_{50}: \mathrm{U}_{50}$ & 4427 A b1 & 20843 ABC a 1 & $4157 \mathrm{~A}$ a 1 & $6760 \mathrm{~A}$ a 2 & 11.56 & 3.92 & 10.42 & 5.42 \\
\hline $\mathrm{T}_{25}: \mathrm{U}_{75}$ & $3127 \mathrm{~A} \mathrm{b1}$ & $16120 \mathrm{CD}$ a 1 & $2720 \mathrm{~A}$ a 1 & 2747 B a 2 & 17.29 & 21.07 & 21.84 & 26.66 \\
\hline
\end{tabular}

T: Triticale, Ü: Ürünlü (leafed forage pea cultivar), U: Ulubatli (semi-leafless forage pea cultivar)

**, year $\mathrm{x}$ harvest time $\mathrm{x}$ treatment interaction is significant $(\mathrm{p}<0.01)$

The difference between treatment means without a common capital letter on the same year and harvest time is significant ( $<<0.05$ )

The difference between harvest time means without a common lower case letter on the same year and treatment is significant $(\mathrm{p}<0.05)$

The difference between year means without a common number on the same harvest time and treatment is significant $(\mathrm{p}<0.05)$

Hay yield and forage pea content of hay varied with years and harvest times (Table 1). Plant species and development stage also influenced hay yield and protein content. Therefore, year $\mathrm{x}$ harvest time $\mathrm{x}$ treatment interaction was found to be significant with regard to crude protein content $(\mathrm{p}<0.01)$. As seen in Table 2, although the highest protein yield of the harvest made at booting stage of triticale of the first year was obtained from $\mathrm{T}_{25}: \ddot{U}_{75}$ treatment, the differences between the other treatments except for $\mathrm{U}_{100}$ were not found to be significant ( $>0.05)$. At the same mowing time, crude protein yields obtained from $\mathrm{T}_{100}$ and $\mathrm{T}_{25}: \ddot{\mathrm{U}}_{75}$ treatments of the second year were significantly lower than the values of the first year, but the differences between the yield values of the treatments were not found to be significant ( $p>0.05)$.

Table 2. Crude protein yield $\left(\mathrm{kg} \mathrm{ha}^{-1}\right)$ of monocrops and mixture of pea with triticale in different seeding ratio harvested at different stages $* *$

\begin{tabular}{|c|c|c|c|c|}
\hline \multirow[b]{2}{*}{ Treatment } & \multicolumn{2}{|c|}{$2010-11$} & \multicolumn{2}{|c|}{ 2011-12 } \\
\hline & Booting & Milk-dough & Booting & Milk-dough \\
\hline $\mathrm{T}_{100}$ & $799.0 \mathrm{AB}$ b 1 & $1842.0 \mathrm{AB}$ a 1 & $311.3 \mathrm{~A} \mathrm{a} 2$ & $358.2 \mathrm{~B}$ a 2 \\
\hline$\ddot{U}_{100}$ & $932.0 \mathrm{AB}$ a 1 & $1196.0 \mathrm{~B}$ a 1 & $597.0 \mathrm{~A} \mathrm{~b} 1$ & $1613.0 \mathrm{~A} \mathrm{a} 1$ \\
\hline $\mathrm{U}_{100}$ & $302.8 \mathrm{~B}$ a 1 & $358.0 \mathrm{C} \mathrm{a} 1$ & $322.7 \mathrm{~A}$ a 1 & 389.1 B a 1 \\
\hline $\mathrm{T}_{75}: \ddot{\mathrm{U}}_{25}$ & $680.3 \mathrm{AB}$ b 1 & $2070.1 \mathrm{~A}$ a 1 & $426.5 \mathrm{~A}$ a 1 & 490.1 B a 2 \\
\hline $\mathrm{T}_{50}: \ddot{\mathrm{U}}_{50}$ & $840.0 \mathrm{AB}$ b 1 & $1759.0 \mathrm{AB}$ a 1 & $506.2 \mathrm{~A}$ a 1 & 618.4 B a 2 \\
\hline $\mathrm{T}_{25}: \ddot{\mathrm{U}}_{75}$ & $1040.0 \mathrm{~A}$ a 1 & $1462.0 \mathrm{AB}$ a 1 & $504.0 \mathrm{~A}$ a 2 & 629.2 B a 2 \\
\hline $\mathrm{T}_{75}: \mathrm{U}_{25}$ & $783.0 \mathrm{AB}$ b 1 & 1537.0 AB a 1 & $331.1 \mathrm{~A}$ a 1 & $658.0 \mathrm{~B}$ a 2 \\
\hline $\mathrm{T}_{50}: \mathrm{U}_{50}$ & $687.0 \mathrm{AB}$ b 1 & 1376.0 B a 1 & $415.4 \mathrm{~A}$ a 1 & $608.1 \mathrm{~B}$ a 2 \\
\hline $\mathrm{T}_{25}: \mathrm{U}_{75}$ & $454.0 \mathrm{AB}$ b 1 & $1492.0 \mathrm{AB}$ a 1 & $322.0 \mathrm{~A}$ a 1 & $282.3 \mathrm{~B}$ a 2 \\
\hline
\end{tabular}

T: Triticale, Ü: Ürünlü (leafed forage pea cultivar), U: Ulubatli (semi-leafless forage pea cultivar)

**, year $\mathrm{x}$ harvest time $\mathrm{x}$ treatment interaction is significant $(\mathrm{p}<0.01)$

The difference between treatment means without a common capital letter on the same year and harvest time is significant $(\mathrm{p}<0.05)$

The difference between harvest time means without a common lower case letter on the same year and treatment is significant ( $<<0.05)$

The difference between year means without a common number on the same harvest time and treatment is significant $(\mathrm{p}<0.05)$

Considering the harvest at milk-dough stage of triticale, the highest crude protein yield of the first year was obtained from $\mathrm{T}_{75}: \ddot{\mathrm{U}}_{25}$ treatment. Although average crude protein yields of $\mathrm{T}_{100}, \mathrm{~T}_{50}: \ddot{\mathrm{U}}_{50}, \mathrm{~T}_{25}: \ddot{\mathrm{U}}_{75}, \mathrm{~T}_{75}: \mathrm{U}_{25}$ and $\mathrm{T}_{25}: \mathrm{U}_{75}$ treatments were slightly lower than the average crude protein yield of $\mathrm{T}_{75}: \ddot{\mathrm{U}}_{25}$ treatment, Tukey test revealed that they all were not significantly different from $\mathrm{T}_{100}$ treatment $(\mathrm{p}>0.05)$. Contrary to the first year of the same harvest time, the highest crude protein yield was obtained from $\ddot{U}_{100}$ treatment. The crude protein yield values of the other treatments lower than $\ddot{U}_{100}$ treatment, but they were not significantly different from each other ( $p>0.05$ ). Except for $\ddot{U}_{100}$ and $\mathrm{U}_{100}$ treatments, crude protein yields of the other treatments in the second year were significantly lower than the values of the first year $(p<0.05)$. When the harvest times were compared, it was observed in the first year that crude protein yields of $\ddot{U}_{100}$, $\mathrm{U}_{100}$ and $\mathrm{T}_{25}: \mathrm{U}_{75}$ treatments did not vary with harvest time, but prolonged harvest time to milk-dough stage of triticale significantly increased crude protein yields of the other treatments $(\mathrm{p}<0.05)$. In the second year, prolonged harvest time increased crude protein yield of $\ddot{U}_{100}$ treatment, but 
did not result in significant differences in crude protein yields of the other treatments ( $p>0.05)$.

Considering all these findings together, increasing crude protein yields were observed in some treatments with prolonged harvest time. When the harvest was performed at milk-dough stage of triticale, $\mathrm{T}_{75}: \ddot{\mathrm{U}}_{25}$, $\mathrm{T}_{50}: \ddot{\mathrm{U}}_{50}, \mathrm{~T}_{75}: \mathrm{U}_{25}$ and $\mathrm{T}_{25}: \mathrm{U}_{75}$ treatments had high average crude protein yields. They had significantly higher crude protein yields than the harvest performed at booting stage of triticale in the first year, and they had also high crude protein yield in both years when harvested at booting stage of triticale. For this reasons, these treatments can be recommended for better crude protein yields (Table 2). As expected, crude protein yields of mixtures were generally higher than the crude protein yields of monocrop triticale (Table 2). Intercropping improved both the hay yield and crude protein ratio of triticale included in the mixture (data were not presented here). The lowest crude protein yield was obtained from monocrop semi-leafless Ulubatl cultivar in both years. The cultivar Ürünlü provided almost 4 folds higher hay yield, therefore the mixtures including Ürünlü cultivar had also higher crude protein yields than the mixture including Ulubatlı cultivar (Table 2).

$\mathrm{ADF}$ and NDF are significant quality criteria providing information on digestibility of forages (Assefa and Ledin, 2001). With regard to ADF and NDF ratios, year $\mathrm{x}$ harvest time and year $\mathrm{x}$ treatment interactions were found to be significant $(\mathrm{P}<0.01)$. Although the lowest $\mathrm{ADF}$ ratio of the first year was observed in $\mathrm{U}_{100}$ treatment, entire treatments are placed in the same statistical group. The highest ADF ratios of the second year were respectively observed in $\mathrm{T}_{25}: \mathrm{U}_{75}, \mathrm{~T}_{50}: \mathrm{U}_{50}$ and $\mathrm{T}_{100}$ treatments. Except for $\mathrm{T}_{75}: \ddot{\mathrm{U}}_{25}, \mathrm{~T}_{50}: \mathrm{U}_{50}$ and $\mathrm{T}_{25}: \mathrm{U}_{75}$ treatments, ADF values of the other treatments significantly decreased in the second year (Table 3). Although Kocer and Albayrak (2012) reported lower ADF ratios for the mixture of forage pea, oat or barley than the ADF ratios of monocrop cereals, ADF ratios of mixtures of the present study were not significantly different from the ADF ratio of monocrop triticale. Such a case was probably because of interspecies competition. Thusly, Lithourgidis et al. (2006) and Budakli Carpici and Celik (2014) indicated that ADF ratios of mixtures weren't lower than monocrop cereals at all time. Besides, forages are classified mostly based on ADF ratios. The fodders with ADF ratios below $31 \%$ are classified as perfect, between $31-35 \%$ as high quality, between $36-40 \%$ as good, between $41-42 \%$ as medium, between $43-45 \%$ as low quality and over $45 \%$ as poor (Anonymous, 2015). Except for the forage obtained from $\mathrm{T}_{100}, \mathrm{~T}_{50}: \mathrm{U}_{50}$ and $\mathrm{T}_{25}: \mathrm{U}_{75}$ treatments, entire forages of the second year were classified as high quality.

Table 3. ADF (\%) and NDF (\%) ratios of hay of monocrops and mixture of pea with triticale in different seeding ratios

\begin{tabular}{|c|c|c|c|c|}
\hline \multirow[b]{2}{*}{ Treatment } & \multicolumn{2}{|r|}{$\mathrm{ADF}^{*}$} & \multicolumn{2}{|r|}{ NDF** } \\
\hline & $2010-11$ & 2011-12 & $2010-11$ & 2011-12 \\
\hline $\mathrm{T}_{100}$ & $40.89 \mathrm{~A} \mathrm{a}$ & $35.99 \mathrm{~A} \mathrm{~b}$ & $67.00 \mathrm{~A} \mathrm{a}$ & $62.89 \mathrm{~A} \mathrm{a}$ \\
\hline$\ddot{U}_{100}$ & $40.46 \mathrm{~A} \mathrm{a}$ & $32.23 \mathrm{AB} b$ & $54.25 \mathrm{~B} \mathrm{a}$ & $42.83 \mathrm{C} \mathrm{b}$ \\
\hline $\mathrm{U}_{100}$. & $39.07 \mathrm{~A} \mathrm{a}$ & $31.13 \mathrm{~B} \mathrm{~b}$ & $51.24 \mathrm{~B} \mathrm{a}$ & $42.53 \mathrm{C} \mathrm{b}$ \\
\hline $\mathrm{T}_{75}: \ddot{\mathrm{U}}_{25}$ & $39.12 \mathrm{~A} \mathrm{a}$ & $34.84 \mathrm{AB}$ a & $62.90 \mathrm{~A} \mathrm{a}$ & $57.94 \mathrm{AB}$ a \\
\hline $\mathrm{T}_{50}: \ddot{\mathrm{U}}_{50}$ & $42.2 \mathrm{~A} \mathrm{a}$ & $34.92 \mathrm{AB} b$ & $64.05 \mathrm{~A} \mathrm{a}$ & $56.73 \mathrm{AB} b$ \\
\hline $\mathrm{T}_{25}: \ddot{\mathrm{U}}_{75}$ & $40.28 \mathrm{~A} \mathrm{a}$ & $34.17 \mathrm{AB} b$ & $61.54 \mathrm{~A} \mathrm{a}$ & $52.98 \mathrm{~B} \mathrm{~b}$ \\
\hline $\mathrm{T}_{75}: \mathrm{U}_{25}$ & $40.63 \mathrm{~A} \mathrm{a}$ & $34.12 \mathrm{AB} b$ & $65.39 \mathrm{~A} \mathrm{a}$ & $60.48 \mathrm{~A} \mathrm{a}$ \\
\hline $\mathrm{T}_{50}: \mathrm{U}_{50}$ & $39.85 \mathrm{~A} \mathrm{a}$ & $36.01 \mathrm{~A} \mathrm{a}$ & $64.61 \mathrm{~A} \mathrm{a}$ & $60.45 \mathrm{~A} \mathrm{a}$ \\
\hline $\mathrm{T}_{25}: \mathrm{U}_{75}$ & $38.55 \mathrm{~A} \mathrm{a}$ & $36.74 \mathrm{~A} \mathrm{a}$ & $61.38 \mathrm{~A} \mathrm{a}$ & $61.26 \mathrm{~A} \mathrm{a}$ \\
\hline
\end{tabular}

\section{Harvest time $^{* *}$}

Booting

$36.50 \mathrm{~B} \mathrm{a}$

35.17 A $a$

$43.74 \mathrm{Aa}$

$33.76 \mathrm{Ab}$

$57.77 \mathrm{~B} \mathrm{a}$

58.24 A $a$

Milk-dough

T: Triticale, Ü: Ürünlü (leafed forage pea cultivar), U: Ulubatli (semi-leafless forage pea cultivar)

For ADF; year $x$ treatment interaction is significant $(p<0.05)$, year $x$ harvest time interaction is significant $(p<0.01)$

For NDF, both year $\mathrm{x}$ treatment interaction and year $\mathrm{x}$ harvest time interaction is significant $(\mathrm{p}<0.01)$

For each traits;

The difference between treatment means without a common capital letter on the same year is significant $(p<0.05)$

The difference between year means without a common capital letter on the same treatment is significant $(\mathrm{p}<0.05)$

The difference between harvest time means without a common italic capital letter on the same year is significant $(p<0.05)$

The difference between year means without a common capital lowercase letter on the same harvest time is significant $(\mathrm{p}<0.05)$

As it was seen in Table 3, the lowest NDF ratios were obtained from monocrop semi-leafless forage pea cultivar (Ulubatll) in both years (respectively with $51.24 \%$ and $42.53 \%$ ), but the differences from leafed forage pea cultivar (Ürünlü) were not found to be significant. The highest NDF values were observed in monocrop triticale (respectively with $67.00 \%$ and $62.89 \%$ ) (Table 3). Legumes have higher amount of tissues with thin cell wall than graminae species. Since NDF provides information about cell wall, legumes commonly have lower NDF ratios than graminae (Tan and Mentese, 2003). In intercropping systems, decreasing NDF ratios were reported with increasing legume ratios in mixtures (Erol et al., 2009). Similarly in this study, NDF ratios decreased with increasing forage pea ratios of mixtures, but the decrease was not parallel to sowing rates. Such a case was probably because of interspecies competition, differences in leaf/shoot ratios of the species and forage pea ratios of 
mixtures. Thusly, Ulubatlı cultivar's hay ratio was placed in all mixtures at lower rate than sowing ratio in both years and harvest times (Table 1).

Considering the harvest times, contrary to expectations, ADF and NDF ratios of the hay decreased in the second year when the harvest was prolonged to milkdough stage of triticale (Table 3 ). Such a case was because of increasing forage pea ratios and decreased shoot ratio of triticale based on kernel fill of triticale. There were more misty days between booting and milk-dough stage of triticale in the second year than in the same period of the first year. Forage pea development throughout the relevant period went on and flowering was observed while lower pods are developing. Therefore, the lowest ADF and NDF ratios were observed in hays harvested at milk-dough stage of triticale in the second year (Table 3 ).

Since climate and harvest time influence hay yield and ADF ratio of the hay, digestible dry matter yields (DDMY) calculated by using these two parameters were also influenced by climate and harvest time. Triticale developed well in the first year and leafed forage pea (Ürünlü) exhibited better growth in the second year. Therefore, dry hay yields and ADF ratios of the treatments varied with years and thus DDMY values also varied with years. With regard to DDMY, year $\mathrm{x}$ harvest time $\mathrm{x}$ treatment interaction was found to be significant $(\mathrm{P}<0.01)$. The differences in DDMY value of the treatments were not found to be significant in both years when the harvest was performed at booting stage of triticale $(p>0.05)$.
Similarly, the differences between the years were not also significant $(\mathrm{p}>0.05)$. Except for $\ddot{U}_{100}$ and $\mathrm{U}_{100}$ treatments, significant increases were observed in DDMY of entire treatments of the first year when the harvest was performed at milk-dough stage of triticale $(\mathrm{p}<0.05)$. In the second year, contrary to the first year, except for $\ddot{U}_{100}$ treatment, significant increases were not observed in DDMY when the harvest was performed at milk-dough stage of triticale $(\mathrm{p}>0.05)$. At relevant harvest time, the highest DDMY of the first year was observed in $\mathrm{T}_{75}: \mathrm{U}_{25}$ treatment and the lowest values were seen in $\ddot{U}_{100}$ and $\mathrm{U}_{100}$ treatments. The treatments $\mathrm{T}_{75}: \mathrm{U}_{25}, \mathrm{~T}_{100}, \mathrm{~T}_{75}: \ddot{\mathrm{U}}_{25}, \mathrm{~T}_{50}: \ddot{\mathrm{U}}_{50}$ and $\mathrm{T}_{25}: \ddot{\mathrm{U}}_{75}$ were not also significantly different with regard to DDMY $(\mathrm{p}>0.05)$. In the second year, $\ddot{U}_{100}$ treatment exhibited lower DDMY values in both years when the harvest was performed at milk-dough stage of triticale and $\ddot{U}_{100}$ was not influenced by the differences in the years. DDMY values of the other treatments significantly decreased in the second year and the highest value was observed in $\ddot{U}_{100}$ treatment. The treatments $\mathrm{T}_{100}$, $\mathrm{T}_{75}: \ddot{\mathrm{U}}_{25}, \mathrm{~T}_{50}: \ddot{\mathrm{U}}_{50}, \mathrm{~T}_{25}: \ddot{\mathrm{U}}_{75}, \mathrm{~T}_{75}: \mathrm{U}_{25}$ and $\mathrm{T}_{50}: \mathrm{U}_{50}$ were not also significantly different from $\ddot{U}_{100}$ in the second year when the harvest was performed at milk-dough stage of triticale ( $p>0.05)$. Since high DDMC is desired in forage, $\mathrm{T}_{100}$, $\mathrm{T}_{75}: \ddot{\mathrm{U}}_{25}, \mathrm{~T}_{50}: \ddot{\mathrm{U}}_{50}, \mathrm{~T}_{75}: \mathrm{U}_{25}$ and $\mathrm{T}_{50}: \mathrm{U}_{50}$ treatments with high yield values in both years when harvested at milk-dough stage of triticale can be recommended for higher DDMY values (Table 4).

Table 4. DDMY of monocrops and mixture of pea with triticale in different seeding ratio harvested at different stages **

\begin{tabular}{|c|c|c|c|c|}
\hline \multirow[b]{2}{*}{ Treatment } & \multicolumn{2}{|c|}{$2010-11$} & \multicolumn{2}{|c|}{ 2011-12 } \\
\hline & Booting & Milk-dough & Booting & Milk-dough \\
\hline $\mathrm{T}_{100}$ & $3069.8 \mathrm{~A} \mathrm{~b} 1$ & $11050.5 \mathrm{AB}$ a 1 & $1718.0 \mathrm{~A}$ a 1 & $2318.7 \mathrm{AB}$ a 2 \\
\hline$\ddot{U}_{100}$ & $2153.5 \mathrm{~A}$ a 1 & $3850.4 \mathrm{D}$ a 1 & 1738.9 A b 1 & 5257.3 A a 1 \\
\hline $\mathrm{U}_{100}$ & $742.8 \mathrm{~A}$ a 1 & $1054.7 \mathrm{D}$ a 1 & $1051.1 \mathrm{~A}$ a 1 & $1375.8 \mathrm{~B}$ a 1 \\
\hline $\mathrm{T}_{75}: \ddot{U}_{25}$ & $2356.2 \mathrm{~A} \mathrm{~b} 1$ & 11092.7 AB a 1 & 2113.1 A a 1 & $2533.3 \mathrm{AB}$ a 2 \\
\hline $\mathrm{T}_{50}: \ddot{\mathrm{U}}_{50}$ & $2761.7 \mathrm{~A} \mathrm{~b} 1$ & $8432.3 \mathrm{ABC}$ a 1 & $2301.0 \mathrm{~A} \mathrm{a} 1$ & $2929.5 \mathrm{AB}$ a 2 \\
\hline $\mathrm{T}_{25}: \ddot{\mathrm{U}}_{75}$ & $2872.5 \mathrm{~A} \mathrm{~b} 1$ & $7588.6 \mathrm{C}$ a 1 & 2118.7 A a 1 & $2869.0 \mathrm{AB}$ a 2 \\
\hline $\mathrm{T}_{75}: \mathrm{U}_{25}$ & 2846.0 A b1 & $11500.2 \mathrm{~A}$ a 1 & 1906.8 A a 1 & 4096.6 AB a 2 \\
\hline $\mathrm{T}_{50}: \mathrm{U}_{50}$ & $2356.2 \mathrm{~A} \mathrm{~b} 1$ & $10757.4 \mathrm{ABC}$ a 1 & $2316.5 \mathrm{~A}$ a 1 & $3735.4 \mathrm{AB}$ a 2 \\
\hline $\mathrm{T}_{25}: \mathrm{U}_{75}$ & $1636.9 \mathrm{~A} \mathrm{~b} 1$ & 8056.9 B a 1 & $1485.7 \mathrm{~A}$ a 1 & $1535.6 \mathrm{~B} \mathrm{a} 2$ \\
\hline
\end{tabular}

T: Triticale, Ü: Ürünlü (leafed forage pea cultivar), U: Ulubatli (semi-leafless forage pea cultivar)

$* *$, year $\mathrm{x}$ harvest time $\mathrm{x}$ treatment interaction is significant $(\mathrm{p}<0.01)$

The difference between treatment means without a common capital letter on the same year and harvest time is significant ( $\mathrm{p}<0.05$ )

The difference between harvest time means without a common lower case letter on the same year and treatment is significant $(\mathrm{p}<0.05)$

The difference between year means without a common number on the same harvest time and treatment is significant $(\mathrm{p}<0.05)$

Friedman and Wilcoxon ranked mark test was performed for Land Equivalent Ratio (LER) values and significant differences were observed in LER values of treatments in both years when the harvest was performed at milk-dough stage of triticale $(\mathrm{p}<0.05)$. At relevant harvest time, entire mixtures of the first year were found to be superior to monocrops (LER > 1). Although only the treatments $\mathrm{T}_{25}: \mathrm{U}_{75}$ and $\mathrm{T}_{50}: \mathrm{U}_{50}$ were superior to monocrops in the second year (LER > 1), significant differences were not observed between these mixtures and the treatments
$\mathrm{T}_{75}: \ddot{\mathrm{U}}_{25}, \mathrm{~T}_{50}: \ddot{\mathrm{U}}_{50}$ and $\mathrm{T}_{25}: \ddot{\mathrm{U}}_{75}$. Regard both years together, $\mathrm{T}_{25}: \mathrm{U}_{75}$ and $\mathrm{T}_{50}: \mathrm{U}_{50}$ treatments were superior to monocrops in both years when the harvest was performed at milkdough stage of triticale (Table 5). Since forage pea and triticale have different root and shoot structures, require different nutrients, have different responds to climate conditions and forage pea supplies $\mathrm{N}$ to triticale, the yields obtained from intercropping systems were higher than the yields obtained from monocropping systems. 
Table 5. Descriptive statistics and comparison results for LER value of mixtures of pea with triticale harvested at different stages

\begin{tabular}{|c|c|c|c|c|c|c|c|c|c|c|c|}
\hline \multirow{2}{*}{ Years } & \multirow{2}{*}{ Ht } & \multicolumn{9}{|c|}{ Treatment } & \multirow{2}{*}{$\begin{array}{c}\text { P- } \\
\text { Value }^{1}\end{array}$} \\
\hline & & $\mathbf{T}_{100}$ & $\ddot{\mathbf{U}}_{100}$ & $\mathbf{U}_{100}$ & $\mathbf{T}_{75}: \ddot{U}_{25}$ & $\mathbf{T}_{50}: \ddot{U}_{50}$ & $\mathrm{~T}_{25}: \ddot{\mathbf{U}}_{75}$ & $\mathbf{T}_{75}: \mathrm{U}_{25}$ & $\mathbf{T}_{50}: \mathbf{U}_{50}$ & $\mathbf{T}_{25}: \mathbf{U}_{75}$ & \\
\hline \multirow{5}{*}{ 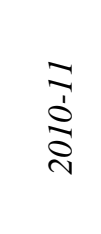 } & \multirow{2}{*}{ B } & 1.00 & 1.00 & 1.00 & 0.95 & 1.23 & 1.60 & 1.06 & 1.06 & 0.87 & \multirow{2}{*}{$0.949^{\mathrm{NS}}$} \\
\hline & & 17.0 & 17.0 & 17.0 & 14.0 & 14.0 & 14.0 & 13.0 & 19.0 & 10.0 & \\
\hline & \multirow{2}{*}{ MD } & 1.00 & 1.00 & 1.00 & 1.28 & 1.28 & 1.11 & 1.35 & 1.32 & 2.09 & \multirow{3}{*}{$0.014 *$} \\
\hline & & $7 b$ & $7 b$ & $7 b$ & $20 a b$ & $13 a b$ & $14 a b$ & $20 a b$ & $20 a b$ & $27 a$ & \\
\hline & $\begin{array}{l}\text { P- } \\
\text { Value }^{2}\end{array}$ & $1.00^{\mathrm{NS}}$ & $1.00^{\mathrm{NS}}$ & $1.00^{\mathrm{NS}}$ & $0.285^{\mathrm{NS}}$ & $1.00^{\mathrm{NS}}$ & $1.00^{\mathrm{NS}}$ & $0.285^{\mathrm{NS}}$ & $0.109^{\mathrm{NS}}$ & $1.00^{\mathrm{NS}}$ & \\
\hline \multirow{5}{*}{ 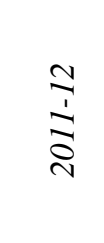 } & \multirow{2}{*}{ B } & 1.00 & 1.00 & 1.00 & 1.24 & 1.36 & 1.22 & 1.18 & 1.47 & 0.98 & \multirow{2}{*}{$0.180^{\mathrm{NS}}$} \\
\hline & & 9.0 & 9.0 & 9.0 & 18.0 & 22.0 & 15.0 & 14.0 & 24.0 & 15.0 & \\
\hline & \multirow{2}{*}{ MD } & 1.00 & 1.00 & 1.00 & 0.90 & 0.97 & 0.84 & 1.73 & 1.69 & 0.81 & \multirow{3}{*}{$0.033^{*}$} \\
\hline & & $15.0 a b$ & $15.0 \mathrm{ab}$ & $15.0 a b$ & $10.0 a b$ & $140 a b$ & $90 a b$ & $26.0 a$ & $25.0 a b$ & $6.0 b$ & \\
\hline & $\begin{array}{l}\text { P- } \\
\text { Value }^{2}\end{array}$ & $1.00^{\mathrm{NS}}$ & $1.00^{\mathrm{NS}}$ & $1.00^{\mathrm{NS}}$ & $0.109^{\mathrm{NS}}$ & $0.285^{\mathrm{NS}}$ & $0.109^{\mathrm{NS}}$ & $0.109^{\mathrm{NS}}$ & $0.109^{\mathrm{NS}}$ & $0.102^{\mathrm{NS}}$ & \\
\hline \multicolumn{2}{|c|}{ P-Value ${ }^{3}$} & $1.00^{\mathrm{NS}}$ & $1.00^{\mathrm{NS}}$ & $1.00^{\mathrm{NS}}$ & $1.00^{\mathrm{NS}}$ & $1.00^{\mathrm{NS}}$ & $1.00^{\mathrm{NS}}$ & $0.109^{\mathrm{NS}}$ & $0.109^{\mathrm{NS}}$ & $1.00^{\mathrm{NS}}$ & $\begin{array}{l}\text { Years in } \\
\text { Ht B }\end{array}$ \\
\hline \multicolumn{2}{|c|}{ P-Value ${ }^{3}$} & $0.109^{\mathrm{NS}}$ & $1.00^{\mathrm{NS}}$ & $0.285^{\mathrm{NS}}$ & $0.285^{\mathrm{NS}}$ & $0.109^{\mathrm{NS}}$ & $0.109^{\mathrm{NS}}$ & $0.285^{\mathrm{NS}}$ & $0.102^{\mathrm{NS}}$ & $0.593^{\mathrm{NS}}$ & $\begin{array}{l}\text { Years in } \\
\mathrm{Ht} \text { MD }\end{array}$ \\
\hline
\end{tabular}

Data are presented in mean rank total.

*Significant according to Friedman/Wilcoxon Ranked mark test $(\mathrm{p}<0.05) ;{ }^{\text {NS }}$, Not -Significant according to Friedman/Wilcoxon Ranked mark test $(\mathrm{p}>0.05)$.

P-Value ${ }^{1}$, Obtained by Friedman test performed to compare the treatments at the same year and harvest time.

P-Value ${ }^{2}$, Obtained by Wilcoxon ranked mark test performed to compare the harvest times at the same year and treatment.

P-Value ${ }^{3}$, Obtained by Wilcoxon ranked mark test performed to compare the years at the same harvest time and treatment.

The differences between the treatments without a common letter at the same year and harvest time are significant according to multiple comparison test $(\mathrm{p}<0.05)$

B: Booting, MD: Milk-dough

Considering the aggressivity (A) and competition ratio (CR) values, competitive characteristics of the species significantly varied with years $(\mathrm{P}<0.01)$. Forage pea was more competitive in the first year and triticale in the second year (Table 6). Besides, significant differences were also observed in aggressivity values of forage pea and triticale $(\mathrm{P}<0.01)$. Except for $\mathrm{T}_{75}: \ddot{\mathrm{U}}_{25}$, while triticale was dominant in entire mixtures $\left(A_{t}\right.$ positive), forage pea was dominant in $\mathrm{T}_{75}: \ddot{\mathrm{U}}_{25}$ treatment ( $A_{p}$ positive) (Table 6). Triticale can tolerate to some decrement in sowing rate with tillering characteristic and tillers grow better in wider sowing than dense sowing. Forage pea was not able to reach close levels in hay to sowing rates in any of mixture (Table 1). Increasing forage pea ratios in mixtures also resulted in increased $\mathrm{N}$ supply to triticale. Therefore, increasing aggressivity levels were observed in triticale with decreasing triticale sowing rates in mixtures. The present findings comply with the results of Dordas et al. (2012) indicating varying interspecies competition levels with species and sowing rates in mixtures. Considering the competition ratio of the forage pea cultivars against triticale, Ürünlü (leafed) was more competitive than Ulubatlı (semi-leafless) in all mixtures (Table 6). This case was caused by higher level of competition between forage pea and triticale for water, nutrient and light, due to probably higher leaf area and habitus of Ürünlü. Thusly, in both years and both harvest times, forage pea ratios in hay of all mixtures including Ulubatlı (semi-leafless) were lower than sowing ratios of forage pea (Table 1).

Table 6. Aggressivity and competitive ratio of mixture of pea with triticale in different seeding ratio

\begin{tabular}{lllll}
\hline Treatment/Year & $\mathbf{A}_{\mathbf{t}}{ }^{* *}$ & $\mathbf{A}_{\mathbf{p}}{ }^{* *}$ & $\mathbf{C R}_{\mathbf{t}}{ }^{* *}$ & $\mathbf{C R}_{\mathbf{p}}{ }^{* * *}$ \\
\hline $\mathrm{T}_{75}: \ddot{U}_{25}$ & $-0.0018 \mathrm{c}$ & $0.0018 \mathrm{a}$ & $1.213 \mathrm{c}$ & $1.262 \mathrm{a}$ \\
$\mathrm{T}_{50}: \ddot{\mathrm{U}}_{50}$ & $0.0045 \mathrm{bc}$ & $-0.0045 \mathrm{ab}$ & $2.083 \mathrm{bc}$ & $0.721 \mathrm{ab}$ \\
$\mathrm{T}_{25}: \ddot{\mathrm{U}}_{75}$ & $0.0101 \mathrm{ab}$ & $-0.0101 \mathrm{bc}$ & $2.734 \mathrm{bc}$ & $0.505 \mathrm{~b}$ \\
$\mathrm{~T}_{75}: \mathrm{U}_{25}$ & $0.0101 \mathrm{ab}$ & $-0.0101 \mathrm{bc}$ & $4.536 \mathrm{ab}$ & $0.451 \mathrm{~b}$ \\
$\mathrm{~T}_{50}: \mathrm{U}_{50}$ & $0.0158 \mathrm{a}$ & $-0.0158 \mathrm{c}$ & $6.411 \mathrm{a}$ & $0.361 \mathrm{~b}$ \\
$\mathrm{~T}_{25}: \mathrm{U}_{75}$ & $0.0128 \mathrm{a}$ & $-0.0128 \mathrm{c}$ & $3.954 \mathrm{abc}$ & $0.417 \mathrm{~b}$ \\
\hline $2010-2011^{* *}$ & $0.003 b$ & $-0.003 a$ & $2.103 b$ & $0.903 a$ \\
$2011-2012$ & $0.014 a$ & $-0.014 b$ & $4.873 a$ & $0.336 b$ \\
\hline
\end{tabular}

T: Triticale, Ü: Ürünlü (leafed forage pea cultivar), U: Ulubatli (semi-leafless forage pea cultivar)

**, Main effects of year and treatment are significant $(\mathrm{p}<0.01)$

At: Aggressivity value for triticale, Ap: Aggressivity value for pea, CRt: Competitive ratio of triticale, CRp: Competitive ratio of pea

The difference between the means without a common letter on the same column is significant $(p<0.05)$. 


\section{CONCLUSIONS}

In this study, forage pea cultivars with different leaf characteristics were intercropped with triticale at different mixtures ratios and species were also monocropped and harvested at different growth stages of triticale. The highest dry hay yields in both years were obtained from $\mathrm{T}_{100}, \mathrm{~T}_{75}: \ddot{\mathrm{U}}_{25}, \mathrm{~T}_{75}: \mathrm{U}_{25}$ and $\mathrm{T}_{50}: \mathrm{U}_{50}$ treatments when the harvest was performed at milk-dough stage of triticale; the highest digestible dry matter contents were obtained from $\mathrm{T}_{100}, \mathrm{~T}_{75}: \ddot{\mathrm{U}}_{25}, \mathrm{~T}_{50}: \ddot{\mathrm{U}}_{50}, \mathrm{~T}_{75}: \mathrm{U}_{25}$ and $\mathrm{T}_{50}: \mathrm{U}_{50}$ treatments of the same harvest stage. Besides, $\ddot{U}_{100}, \mathrm{~T}_{75}: \ddot{\mathrm{U}}_{25}, \mathrm{~T}_{50}: \ddot{\mathrm{U}}_{50}$, $\mathrm{T}_{75}: \mathrm{U}_{25}$ and $\mathrm{T}_{25}: \mathrm{U}_{75}$ treatments had high crude protein yields at relevant harvest stage. Considering digestible dry matter yields and crude protein contents together, it was concluded that $\mathrm{T}_{75}: \ddot{\mathrm{U}}_{25}, \mathrm{~T}_{50}: \ddot{\mathrm{U}}_{50}, \mathrm{~T}_{75}: \mathrm{U}_{25}$ mixtures should be grown in similar ecologies and mixtures should be harvested at milk-dough stage of triticale for better yield parameters.

\section{LITERATURE CITED}

Acikgoz, E. 2001. Forages. VIPAS A.S. Press.

Acikgoz, E., A. Ustun, I. GuI, E. Anlarsal, A.S. Tekeli, I. Nizam, R. Avcioglu, H. Geren, S. Cakmakci, B. Aydinoglu, C. Yucel, M. Avci, Z. Acar, I. Ayan, A. Uzun, U. Bilgili, M. Sincik and M. Yavuz. 2009. Genotype x environment interaction and stability analysis for dry matter and seed yield in field pea (Pisum sativum L.). Span J. Agric Res. 7(1):96-106.

Agegnehu, G., A. Ghizaw and W. Sinebo. 2006. Yield performance and land-use efficiency of barley and faba bean mixed cropping in Ethiopian highlands. Eur J. Agron. 25:202-207.

Anonymous, 2015. Deciphering hay quality, http://www.ker.com/library/ equinews/v9n210.pdf, (Accessed May 26, 2015)

Asik, F.F. 2006. The effect of mixture rates and cutting stages on hay yield and quality characters of of pea (Pisum sativum L.) + barley (Hordeum vulgare L.) mixture. Uludag University Institute of Science, Master's Thesis.

Assefa, G. and I. Ledin. 2001. Effect of variety, soil type and fertiliser on the establishment, growth, forage yield, quality and voluntary intake by cattle of oats and vetches cultivated in pure stands and mixtures. Anim Feed Sci Tech. 92:95111.

Berkenkamp, B. and J. Meeres. 1987. Mixtures of annual crops for forage in central Alberta. Can J. Plant Sci. 67:175-183.

Bilgili, U., A. Uzun, M. Sincik, M. Yavuz, B. Aydinoglu, S. Cakmakci, H. Geren, R. Avcioglu, I. Nizam, S. Tekeli, I. Gul, E. Anlarsal, C. Yucel, M. Avci, Z. Acar, I. Ayan, A. Ustun and E. Acikgoz. 2010. Forage yield and lodging traits in peas (Pisum sativum L.) with different leaf types. Turk J. Field Crops. 15(1):50-53.

Budakli Carpici, E. and N. Celik. 2014. Forage yield and quality of common vetch mixtures with triticale and annual ryegrass. Turk J. Field Crops. 19(1): 66-69.
Dhima, K.V., A.S. Lithourgidis, I.B. Vasilakoglou and C.A. Dordas. 2007. Competition indices of common vetch and cereal intercrops in two seeding ratio. Field Crop Res. 100:249-256.

Dordas, C.A., D.N. Vlachostergios and A.S. Lithourgidis. 2012. Growth Dynamics and agronomic-economic benefits of peaoat and pea-barley intercrops. Crop and Pasture Sci. 63:4552.

Duzgunes, O., T. Kesici, O. Kavuncu and F. Gurbuz. 1987. Research and Experimental Methods (Statistical MethodsII). University of Ankara, Faculty of Agriculture Press.

Erol, A., M. Kaplan and M. Kizilsimsek. 2009. Oats (Avena sativa)- common vetch (Vicia sativa) mixtures grown on a low-input basis for a sustainable agriculture. Tropical Grasslands. 43: 191-196.

Horrocks, R.D. and J.F. Vallentine. 1999. Harvested Forages. Academic Pres.

Kocer, A. and S. Albayrak. 2012. Determination of forage yield and quality of pea (Pisum sativum L.) mixtures with oat and barley. Turk J. Field Crops. 17(1):96-99.

Lithourgidis A.S., I.B. Vasilakoglou, K.V. Dhima, C.A. Dordas and M.D. Yiakoulaki. 2006. Forage yield and quality of common vetch mixtures with oat and triticale in two seeding ratios. Field Crops Researches. 99:106-113.

Lithourgidis, A.S., D.N. Vlachostergios, C.A. Dordas and C.A. Damalas. 2011. Dry matter yield, nitrogen content, and competition in pea-cereal intercropping systems. Eur J. Agron. 34:287-294.

Mead, R. and R.W. Willey. 1980. The concept of a land equivalent ratio and advantages in yields for intercropping. Exp Agr. 16:217-228.

Mut, Z., I. Ayan and H. Mut. 2006. Evaluation of forage yield and quality at two phenological stages of triticale genotypes and other cereals grown under rainfed conditions. Bangl $\mathbf{J}$. Bot. 35(1):45-53.

Tamkoc, A., A. Ustun, S. Altinok and E. Acikgoz. 2009. Biomass and seed yield stability of pea genotypes. J. Food, Agric Env. 7(1):140-146.

Tan, M. and O. Mentese. 2003. Effects of anatomic structure and chemical composition on forage quality. J. of Atatürk Univ. Agriz. Fac. 34(1):97-103.

Turk, M., S. Albayrak and O. Yuksel. 2011. Effect of seeding rate on the forage yields and quality in pea cultivars of differing leaf types. Turk J. Field Crops. 16(2):137-141.

Uzun, A. and E. Acikgoz. 1998. Effect of sowing season and seeding rate on the morphological traits and yields in pea cultivars of differing leaf types. J. Agron Crop Sci. 181:215222.

Uzun, A., U. Bilgili, M. Sincik, I. Filya and E. Acikgoz. 2005. Yield and quality of forage type pea lines of contrasting leaf types. Eur J. Agron. 22:85-94.

Uzun, A. and F.F. Asik. 2012. The effect of mixture rates and cutting stages on some yield and quality characters of pea (Pisum sativum L.) + oat (Avena sativa L.) mixture. Turk J. Field Crops. 17(1):62-66. 